\title{
Not Only About Price but Also Lifestyle: Recent Phenomena of Backpacker Umrah in Indonesia
}

\author{
Pitaya \\ Universitas Gadjah Mada, Indonesia \\ email: pitaya_p@ugm.ac.id \\ Ghifari Yuristiadhi Masyhari Makhasi \\ Universitas Gadjah Mada, Indonesia \\ email: ghifari.yuristiadhi@ugm.ac.id \\ Mohd Hafiz Hanafiah \\ Universiti Teknologi MARA, Malaysia \\ email: hafizhanafiah@salam.uitm.edu.my
}

\begin{abstract}
The increasing interest of the Indonesian Muslim community to perform umrah has been previously studied by many researchers. However, the phenomenon of backpacker umrah, which has attracted the middle-class Muslim community in Indonesia in the last decade, has not been widely discussed. Backpacker umrah is different from conventional umrah because it does not get complete facilities from travel agencies, so the price is lower. This study explores the motivation of umrah pilgrims to choose backpacker umrah solely because of lower prices or other considerations. Then how far is the response of umrah travel agents to this new trend? This type of research is qualitative research that uses a phenomenological approach. The method used was the observation, questionnaires, and unstructured interviews with 15 backpacker umrah participants determined by a snowball. The results of this study indicate that there are other motivations besides low prices, namely lifestyle. In addition, the selection of the type of umrah that is not tied to a schedule can be more solemn in worship. Although it does not publish directly as one of its products, the umrah travel agency responds to this backpacker umrah phenomenon by seeing it as an economic opportunity by providing land arrangement facilities.
\end{abstract}

Keywords: backpacker umrah; cheap umrah; umrah phenomena; pilgrimage tours; religious tourism

Abstrak: Meningkatnya minat masyarakat muslim Indonesia untuk melakukan umrah sudah banyak dikaji oleh peneliti. Namun fenomena umroh backpacker yang menarik minat masyarakat muslim kelas menengah di Indonesia dalam satu dekade terakhir ini belum banyak didiskusikan. Umroh backpacker berbeda dengan umroh konvensional karena tidak mendapatkan fasilitas yang lengkap dari biro perjalanan sehingga harganya lebih murah. Penelitian ini

Economica: Jurnal Ekonomi Islam - Volume 12, Nomor 1 (2021) 
menggali motivasi jemaah umrah memilih backpacker umrah semata-mata karena harga yang lebih murah atau pertimbangan lain. Lalu sejauh mana respon travel agent umrah terhadap tren baru ini? Jenis penelitian ini adalah penelitian kualitatif yang menggunakan pendekatan fenomenologis. Metode yang digunakan adalah observasi, angket, dan wawancara tidak terstruktur dengan 15 peserta umroh backpacker yang ditentukan dengan bola salju. Hasil enelitian ini menunjukkan bahwa ada motivasi lain selain harga yang murah yaitu gaya hidup. Selain itu, pemilihan jenis umroh yang tidak terikat jadwal bisa lebih khusyuk dalam beribadah. Meski tidak mempublikasikan secara langsung sebagai salah satu produknya, biro perjalanan umrah merespon fenomena umrah backpacker ini dengan melihat sebagai peluang ekonomi dengan memberikan fasilitas land arrangement.

Kata Kunci: umrah backpacker; umrah murah; fenomena umrah; wisata ziarah; wisata religi 
Not Only About Price but Also Lifestyle: Recent Phenomena of ...

\section{Introduction}

Indonesia has a majority Muslim population, with $87.2 \%$ of the 255 million population (Hefner 2017). In the last two decades, the Indonesian Muslim community has grown as a middle class with strong economic power that presents a growing expression of religiosity (Jati 2015). The increasing interest and awareness of halal products, including food (Masruroh 2020) and tourism activities, reflects the religiosity of Indonesian society in the contemporary period. This phenomenon is related to the increase in umrah pilgrims from Indonesia from year to year.

Data from the Ministry of Religion of the Republic of Indonesia in 2016 shows that the number of Indonesian umrah pilgrims is 699,612 and 7\% from the previous year. In 2018 Republika noted that Indonesian umrah pilgrims reached 1 million (Z. Oktaviani 2018). Apart from the conventional umrah model with complete facilities from the umrah and hajj travel agency, known as the backpacker umrah. Slightly different from in Indonesia, in Malaysia, this umrah model is better known as do it yourself (DIY) umrah (Shamsuddin 2019).

In the last five years, Indonesia has seen the phenomenon of the backpacker umrah boom. This backpacker umrah has been growing around since 2010 (Prodjo 2017). However, not many people knew about the backpacker umrah because the information about the backpacker umrah not widely spread yet, and the many travel agents for Hajj and umrah travel agencies do not openly offer backpacker umrah pilgrimage packages to prospective pilgrims.

Umrah backpacker is an independent umrah with a relatively cheaper cost than the cost of umrah in general. Based on the definition of the backpacker umrah, the backpacker umrah uses some leading characteristics in its implementation. These included: not following the umrah travel agency itinerary, no time limit, visiting tourist places that rarely visited on regular 
umrah trips, cheap, free to choose where to stay, not being bound by other group schedules, popular with young people, and being able to worship more solemnly (Hidayat 2019). Briefly, the differences between backpacker umrah and regular umrah are set out in the following table 1.

This backpacker umrah is also known as independent umrah because it is in the process of taking care of before and after umrah's departure without using the services of a hajj and umrah travel agency, except in visa processing. In this backpacker umrah, the pilgrims look for plane tickets, chooses hotels while in Saudi Arabia, takes care of the needs of umrah departure and return, and so on independently. However, prospective umrah pilgrims take care of the backpacker umrah needs in groups (Interview with Yusuf Al Ayubi, umrah travel agency officer based on Yogyakarta). Briefly, the differences between backpacker umrah and regular umrah are shown in Table 1.

Tabel 1. Distinction between backpacker umrah and Regular umrah

\begin{tabular}{ll}
\hline \multicolumn{1}{c}{ backpacker umrah } & \multicolumn{1}{c}{ Regular umrah } \\
\hline $\begin{array}{l}\text { Participants are free to arrange the } \\
\text { itinerary with other groups }\end{array}$ & $\begin{array}{l}\text { Participants follow the itinerary } \\
\text { determined by umrah travel. }\end{array}$ \\
$\begin{array}{l}\text { Participants are free to determine the } \\
\text { duration of umrah }\end{array}$ & $\begin{array}{l}\text { Participants determine the duration of } \\
\text { umrah according to the type of umrah } \\
\text { package taken. }\end{array}$ \\
$\begin{array}{l}\text { Participants are free to decide on the } \\
\text { destination they want to visit on the } \\
\text { sidelines of the umrah pilgrimage }\end{array}$ & $\begin{array}{l}\text { Participants take part in a city tour } \\
\text { package in Makkah or Madinah according } \\
\text { to the package arranged by umrah travel. }\end{array}$ \\
$\begin{array}{l}\text { Participants are free to decide on the time } \\
\text { and airline to go and return }\end{array}$ & $\begin{array}{l}\text { Participants follow flight schedules } \\
\text { determined by umrah travel, while the } \\
\text { airline adjusts the selected umrah package. }\end{array}$ \\
$\begin{array}{l}\text { Participants are free to decide on the } \\
\text { location, duration of stay, and the type of } \\
\text { accommodation they want to use }\end{array}$ & $\begin{array}{l}\text { Participants get an accommodation choice } \\
\text { according to the package. }\end{array}$ \\
$\begin{array}{l}\text { Participants are free to choose a restaurant } \\
\text { or type of food during umrah }\end{array}$ & $\begin{array}{l}\text { Participants get food in the same package } \\
\text { with accommodation services used } \\
\text { according to the umrah package taken. } \\
\begin{array}{l}\text { Participants must seek land arrangements } \\
\text { facilitated by umrah travel in Indonesia }\end{array}\end{array}$ \\
\hline $\begin{array}{l}\text { Participants do not need to look for land } \\
\text { arrangements in Saudi Arabia because all } \\
\text { services are facilitated by umrah travel. }\end{array}$
\end{tabular}

Source: Processed research data 
Many people in Indonesia are interested in the backpacker umrah because of several things. Namely, this backpacker umrah trip is very cost and time-efficient. umrah, in the backpacker way, prospective pilgrims can carry out the umrah pilgrimage at a cost that tends to be cheaper than the regular umrah fee. Suppose the cost of regular umrah, in general, is between twenty and thirty million -based on the type and facility for its pilgrims, then with a backpacker umrah. In that case, the cost is less than twenty million. Nevertheless, regarding the minimum price limit for umrah, the Minister of Religion of the Republic of Indonesia has issued Regulation of the Minister of Religion (PMA) No. 8 of 2018 concerning the umrah Worship Organizing, which limits the minimum cost of organizing umrah to 20 million (Indonesia 2018).

In addition, with the backpacker umrah, the prospective pilgrims do not only perform umrah worship. However, the prospective pilgrims can also make pilgrimages and vacations in various countries that the prospective pilgrim wants. In addition, the benefits of this backpacker umrah, prospective pilgrims are also free from the attachments of the Hajj and umrah travel agencies (Hidayat 2019).

Many researchers have previously carried out studies on the development of umrah worship in Indonesia. Some of the themes are discussing legal protection for umrah pilgrims (Mukhlis 2018; Arif 2019), obstacles to the implementation of umrah (Dani 2018), technological innovations for umrah (Oktoyadi and Wahyuni 2019; N. Oktaviani and Sauda 2019; Setiawan and Sari 2020), the law on bailout funds and umrah financing from a muammalat perspective (Intansari and Zahroh 2019; Ronan 2018), government policies related to umrah (Rohilah 2018), to case studies of umrah travel agency services (Rohmatillah and Ridho 2021; Syafira and Murtani 2020). Different from others, Dewi analyzes umrah as a trend and the strengthening of community spiritualism, which is responded to by religious capitalization (Dewi 2017). Suppose Dewi's study criticizes the phenomenon 
of religious capitalization wrapped in Sunnah branding in umrah. In that case, this paper is more specific in reviewing backpacker umrah as a Muslim middle-class lifestyle in the last decade. With this limitation, it appears that the novelty of this article compared to previous studies.

\section{Literature review}

\section{Backpacker as a traveling preference}

Markward, in backpackers: The Next Generation, writes the history of the journey of low-cost tourists from drifters to flash-packers and techno-packers. (Markward 2008). While Walsh, in The Social Performance of Backpacking: An Ontogenesis, analyzes the origins of backpacking travel and its forming factors. (Walsh 2014). In backpacker Mobilities: The Practice and Performance of Travelerscapes in a Global World, O' Regans details backpacker mobility in a globalized world (O' Regan 2010). Whereas Wallstam, in backpacker Institutionalization Towards an Experience Based Typology, describes the character of the backpacker concerning the forms of experience (Wallstam 2011).

As a traveling preference, backpacker has a long history (Pitaya et al. 2019). However, a backpacker is academically discussed for the first time by an Australian researcher, Philip Pearce, in 1990 in The backpacker Phenomenon: Preliminary Answers to Basic Questions. The paper states that backpacking travel is more an approach to travel and vacation models than categorizing age and costs spent. Meanwhile, backpackers are low-cost travelers, consisting of young people whose phenomena can identify in five criteria, namely: Choice of low-cost accommodation modes; Emphasis on meeting with other travelers; Self-organized and flexible travel schedule; The duration of the trip is longer than holidays in general; and Emphasis on informal matters and participation in holiday activities (Pearce 1990). 
Not Only About Price but Also Lifestyle: Recent Phenomena of ...

Majstorovic, Stankov, and Stojanov (2013) stated that "the backpackers choose to live in low-cost accommodation, they spend far more time traveling than most tourists, and they enjoy interaction with people, both local people, and fellow tourists." Meanwhile, In their writing, Pearce and Foster state that a backpacker is a traveling university (Pearce and Foster 2007).

The meaning of the two said that there was nothing but much learning that he termed generic skills in tourists developed and the backpacker activities he did. According to both, the skills honed during the backpacker are instrumental in the world of work. Therefore, he said that the backpacker is a learning medium. A backpacker's motivation will differ from other backpackers based on nation and culture, age, gender, and social class. Therefore, they tend to have almost the same interest in travel routes (Maoz 2007).

As a backpacker learning medium, there are many risks. Some of the risks a backpacker faces include the distance of expectations, physical, health, financial, political, and psychosocial. Therefore, a backpacker must have the ability to reduce the risks he is likely to face (Adam 2015). In addition, outbreaks of emerging diseases such as COVID 19, which today spread in many countries, have significantly affected backpacker mobility. For example, Gautret et al. (2011) noted how backpackers in Thailand were quite intense in asking and looking for information about the rabies virus developing there. In particular, in his notes, some backpackers pay attention and ask questions very intensively, such as backpackers from England and Ireland.

The wave of backpacking, the ease of air transportation, and the hotel reservation process through the application are getting faster. National boundaries, culture, customs, and even politics are now dissolving as people want to know more about situations in other parts of the world. So that gave rise to the term "Global Nomad" (Jarvis and Peel 2010). If fellow backpackers meet, they will share information about a new place known as word of mouth (WOM). A good destination will be easily spread to others through WOM, 
which quickly presents the motivation, a sense of belonging, social interaction for a destination (Alves et al. 2016).

\section{Backpacker umrah}

Research, especially in the backpacker umrah topic, is not much. Referring to Maoz, perhaps because of the background of Indonesia's predominantly Muslim population, the motivation to worship in the holy land by backpacking becomes higher as the opportunity for Hajj also has to queue quite long (Maoz 2007). In addition, the desire to worship directly at the Masjidil Haram and Masjid Nabawi has become a separate motivation for the Indonesian Muslim community to perform umrah. Some people with high welfare even do it once a year, even twice a year. After departing once with full service and facilities from the umrah travel agency, there was a desire to try a different model of umrah in the next opportunity.

Haadiy (2015) said that the implementation of umrah for the Muslim community in Indonesia is still quite expensive because it has to cost tens to tens of millions of rupiah for tour and travel parties or so on. It is called a normal umrah. In contrast to ordinary umrah, where we only need to pay and get certainty to go for umrah with all matters that will be facilitated, backpacker umrah can be independent because they start looking for cheaper flights, accommodation, consumption, and others. Pilgrims decide themselves, and some other things that we cannot take care of, such as visas, mutawif, and land arrangements, will be assisted by the provider from a local travel agency (Hidayat 2019).

\section{Methods}

This type of research is qualitative research using a phenomenological approach. The data collection used observation, questionnaires, and unstructured interviews with 15 umrah pilgrims. Because it is not easy to find a specific subject that has done backpacker umrah, this study used snowball 
to find a group of backpacker umrah participants with various professional backgrounds and domiciles. The interview also did with umrah travel agency officer based in Yogyakarta with backpacker umrah product and umrah travel owner based on Sukoharjo and Probolinggo. These umrah travel agencies were determined by random. The Researcher carried out the observation by participating in backpacker umrah on 28 February-10 March 2017.

The data collected in this study are the various motivations of the pilgrims to perform backpacker umrah from the pilgrims, the requirements and regulations that the pilgrims fulfill to take a backpacker umrah from an umrah travel agency, and pilgrims' experiences during umrah backpacker. Data analysis in this study is a systematic arrangement of notes obtained from interviews, observations, and documents to summarize the research results. Data analysis includes tracking activities, organizing, solving, and searching for patterns (Subana, M. and Sudrajat 2011). In the data analysis process, the researcher interpreted. Interpretation is to sharpen the focus of observation and deepen the problem relevant to the direction of the problem. The data was analyzed using Moleong's four types in qualitative research: data reduction, data presentation, concluding, and verification (Moleong 2014).

\section{Result and discussion}

The subject of this research was $46.6 \%$ male and $53.3 \%$ female, in a total of 15 persons. The spreading questionnaires and interviews with 15 subjects who do the backpacker umrah show that, on average, they perform a backpacker umrah for at least one week and a maximum of 2 weeks because mostly they have a formal occupation in Indonesia cannot leave long. More than half, or $53.3 \%$ to be exact, do this backpacker umrah for nine days. The second highest position as those who did the backpacker umrah is $33.3 \%$. Meanwhile, a small proportion of them, namely $13.3 \%$, did umrah backpackers for 14 days. None of the sources answered that they did the backpacker umrah for three weeks or four weeks. Whereas based on the 
number of groups in backpacker umrah trip, all informants answered above 20 people. No one answered less than 20 people, including those who departed individually.

Asked about the costs incurred for the backpacker's umrah, the informants spent an average of no more than 20 million. $66.6 \%$ of them answered that 10-15 million at least be spent on each trip. 20\% answered 1520 million. Meanwhile, a small proportion, namely 13.3\%, answered only 510 million rupiah. None of the sources answered that he had to spend more than 20 million travel expenses or less than 5 million. All informants answered on plane tickets as asked about what aspects of the cost savings when performing the backpacker umrah. No one answered that they made savings on financing accommodation, food, beverages, shopping, or anything else.

Questioning the motivation to do the backpacker umrah, of the 15 sources, mostly $80 \%$, answered that they did it because of the low cost. Meanwhile, the other 20\% answered that the backpacker umrah had become the resource's lifestyle. No one answered that they were influenced by social media, just following trends or other reasons.

\section{Backpacker umrah: a pilgrim's experience}

Backpacker umrah is also known by several other terms, such as independent umrah, cheap umrah, or frugal umrah. As a form of travel, the backpacker umrah develops with several variations. The definition that is not single makes the backpacker umrah, independent umrah, and economical or cheap umrah the same. Nevertheless, like Fika Anaira in her blog, some distinguish between backpacker umrah and independent umrah. For example, umrah backpacker defines "umrah who is alone, carrying a backpack, without a tour, and sleeping in a hostel." Meanwhile, independent umrah means "more on hunting for promo tickets yourself then looking for other partners in the group to go together but still use the services of an umrah travel agency" (Anaira 2019). 
The principle of the backpacker umrah that most distinguishes it from regular umrah is how umrah participants are free to determine the time and airline to use based on the promo tickets they get. Therefore, it is possible to get ticket prices that vary with different airlines between one participant and another participant. In addition, after meeting with other colleagues in other backpacker umrah groups, it can be via Facebook or WhatsApp, then determine a travel agency that will take care of the land arrangement. This land arrangement includes administrative requirements, local transportation while in Saudi Arabia, and other equipment needed, starting from umrah visas, airport handling, all tips and taxes, experienced tour guides, city tours of Makkah, Medina, Jeddah (free snacks), equipment (suitcases, ihroms, gowns, and prayer books), and zam-zam 5 liters. The travel agency that manages the land arrangement will agree upon the packages and facilities sold according to the participants' wishes. Then, the total cost of umrah from the ticket obtained added to the cost of the land arrangement while in Saudi Arabia.

Regarding the route, one of the routes that are a favorite of travel agents in designing travel routes is Jakarta/origin city-Kuala Lumpur-JeddahMedina-Makkah-Jeddah-Jakarta-origin city. Kuala Lumpur is still a favorite hub for heading to Saudi Arabia with the paramount consideration of the availability of promo tickets from Malaysia Airlines and the choice of flight routes from various airlines. Several other options include Bangkok or Manila, primarily considering airline ticket prices (Hidayat 2019). Several other cities as transits were also considered based on aircraft routes, such as Oman for Oman Air, Dubai for Emirates, Abu Dhabi for Etihad, Colombo for Sri Lanka Air, and other cities.

Regarding promo tickets illustrated by the sources obtained by researchers, the source gives a sample that she had received a ticket for RM 199 or the equivalent of IDR 8 million (for an exchange rate of RM $1=$ IDR 4000) for a full-service flight from Malaysia Airlines from Kuala Lumpur to Jeddah round trip. The hotel price obtained is also only IDR 1. On the other 
hand, the ticket price obtained by blog writer Fika Anaira is even cheaper. He got a Malaysia Airlines round-trip ticket from Kuala Lumpur International Airport to Prince Mohammad Abdul Aziz Airport in Madinah for IDR 2,869,944 as hunting results in the Tiket Gledek promo from tiket.com, a ticket booking platform. He also had the option of using Oman Air, whose promo ticket price was around IDR 3,600,000, to King Abdul Aziz Airport in Jeddah.

Tabel 2. Itinerary of independent umrah

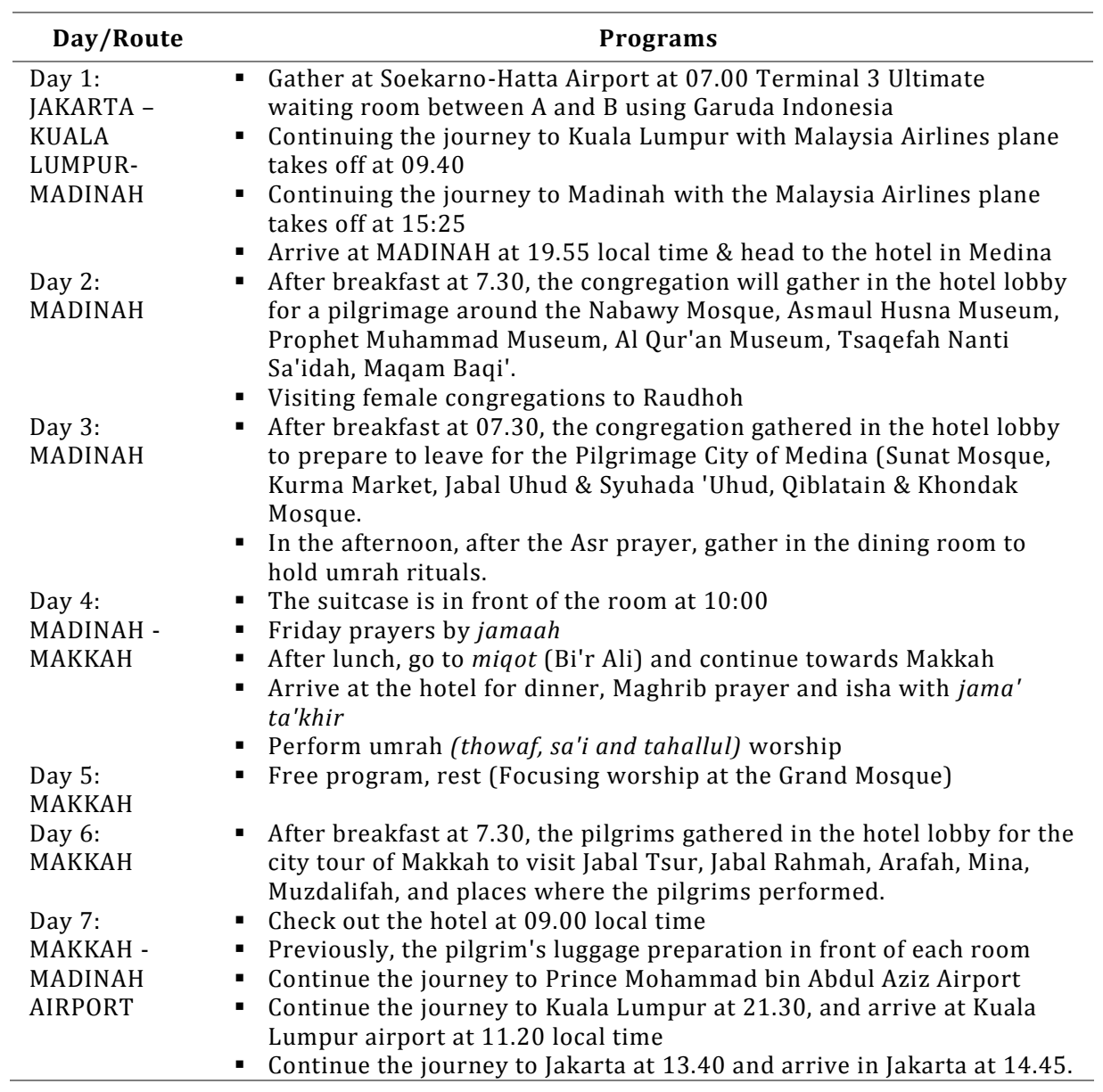

Resource: (Anaira 2019) 
Regarding the itinerary for a backpacker umrah trip, she had assisted by the land arrangement by an umrah travel agency. It is relatively the same as regular umrah, only adjusting the number of days. However, the itinerary will significantly adjust to what the umrah participants want. An informant said another backpacking umrah model in Ramadan, which focuses on Masjid Nabawi while in Medina and Masjidil Haram while in Makkah for worship. There are also many enthusiasts of umrah backpackers during Ramadan (Interview with Yusuf Al Ayubi, umrah travel agency officer based on Yogyakarta).

In the itinerary aspect, independent umrah is sometimes very close to regular umrah. Tabel 2 is an example of a backpacker or independent umrah itinerary as described by Fika Anaira.

\section{Umrah as middle-class pilgrimage}

Based on the data mentioned in the results, the backpacker umrah was not only based on low prices. More than that, the backpacker umrah has become a lifestyle. If tourism has shifted from tertiary to secondary and even primary needs, this umrah trip has transformed into a trend and lifestyle for Muslim communities, especially for the middle income. In further exploring the interviews conducted, the backpacker umrah participants' professional backgrounds dominated by people in business, doctors, and lecturers, categorized as the middle-class category.

According to BPS, the Muslim population in Indonesia is $87.7 \%$ or more than 207 million people. Reading this, Ali (2017) notes in Tirto that he predicts that assuming $56.7 \%$ of Indonesia's population is in cities, in 2020, the number of Muslims living in cities is nearly 137 million, while those living in villages are 104 million. Further, this phenomenon trend will continue to grow.

Still, according to Ali (2017), notes explicitly that urban people have a symbolic religious style. Because of that, according to him, the symbols of piety in urban society are easily recognized on the surface. Moreover, according to 
him, these symbols are connected with consumerism towards halal products, getting stronger. Islamic fashion outlets and shops are also increasingly in demand; TV shows more Islamic events, such as soap operas. In short, the Islamic lifestyle has strengthened in urban communities.

The researcher added that in addition to expressive symbolic diversity, Muslims who live in urban areas also have high religious enthusiasm and easy access to various religious information. It is this religious passion that presents the increasing spiritualism of urban communities. Moreover, this urban society fills most of the middle class (Yusdani et al. 2020).

Analysis from the Boston Consulting Group (BCG) quoted by Ali explains that Indonesia's middle-class population will grow to $62.8 \%$ from 267 million people in 2020. This data also shows us that the proportion of the uppermiddle class reaches $18.4 \%$, the middle class $25.5 \%$, and the lower middle class (emerging middle) at $18.9 \%$. In particular, only the Muslim middle class, whose population is $87.7 \%$, estimated that by 2020 it would reach 233 million people. Thus, according to this BCG data, $62.8 \%$ of the Indonesian Muslims whom the middle-class population will reach 147 million people by 2020; with details of the Muslim upper-middle class of 27 million, the Muslim middle class of 37.5 Muslim lower middle class 27.7 million (Ali 2017). What a significant number.

This growing middle-class Muslim is essential to observe. Middle-class Muslims have high purchasing power and care about the product, excellent service, and the religious aspects of the products used (Ali 2017). Likewise, in the umrah case, this middle class can become a population with high purchasing power, known from the average age of umrah backpacker participants between 25-50 years. They are selective in having umrah package products. Because of their religiousness, they only focus on worship during umrah, so they do not need services that they think are unnecessary, such as city tours, star hotels, and other supporting facilities. These are the religious lifestyle of the new urban middle-class community related to umrah. 
In contrast, this study found that the middle-lower class in a rural or small city with the professions of farmer and trader mainly chose the standard umrah package and even the VIP. This trend occurs in small towns, such as Probolinggo and Sukoharjo (Interview with Rita Wijayanti and Muhammad Tri Wibowo, umrah travel agency owner based on Probolinggo and Sukoharjo). They take the standard and VIP packages because they are unwilling to bother during the trip and more comfortable choices. Higher prices are not a problem because the umrah trips do not need high intensity and are effortless. The interest of the lower middle class for umrah is interesting to see further because they have been enjoying the pilgrimage to the tombs of Wali as a form of religious expression among Indonesian traditionalist Muslims (Fahmi Prihantoro, Makhasi, and Abdillah 2019; F Prihantoro and Yuristiadhi 2018). This thing is different from the middle class, most of whom live in these big cities. They love more make this pilgrimage freely and not depend on the travel agency arrangement. Moreover, they do not only once or twice in their lifetime perform this umrah.

\section{The response of the umrah travel agency to the backpacker umrah}

In order to respond to umrah as a new trend and lifestyle for middle-class Muslims, umrah backpackers have received several kinds of responses from umrah travel agents. The umrah travel agency has chosen several terms. Some umrah travel agencies refer to it as "independent umrah." Some also call it "thrifty umrah" or "cheap umrah" (Interview with Yusuf Al Ayubi, umrah travel agency officer based on Yogyakarta).

Referring to several packages offered by umrah travel agencies, backpacker umrah or independent umrah or economic umrah phenomena is interesting to look more detail. At each package, several umrah travel agencies are trying to offer to see the differences in each to capture opportunities for high interest and the presence of a lifestyle to performing umrah worship. 


\section{Thrifty umrah}

With the company name Y Tour and Travel, PT X is developing an economic umrah package with nine days. The cost offered is 18.5 million, which is still below the minimum standard for the umrah package price set by the Ministry of Religion, 20 million (Indonesia 2018). The facilities offered are round-trip Jakarta-Jeddah tickets, umrah visas, three times daily meals from Indonesian menus, mentors and muthowif, AC buses, city tours of Makkah and Medina, 5 liters of zam-zam water, preparation of umrah (manasik), and equipment such as ID cards and prayer books. This fee does not cover passports, meningitis vaccines, insurance, local transportation (naqobah), luggage, uniforms, and ihram.

If calculated, the cost of IDR 18.5 million still has to be added to the meningitis vaccine of IDR 305,000, an ordinary passport of IDR 300,000, SAR 189 for umrah insurance, SAR 100 of local transportation, suitcases, uniforms, and ihram cloth around IDR 750,000. In total, the needs not included in the 1.8 million will reach over 21 million. This seems cheap in PT X packages, but the price is above the minimum standard for the umrah package price set by the government. Impressed this package offers economical and cheap but, it is actually standard.

\section{Independent umrah}

For this independent umrah model, no umrah travel agency has explicitly made publications. If logged in, umrah travel agencies cannot get maximum benefit if they only open an independent umrah, which only manages land arrangements outside the airline. However, the profit margin from airline tickets is quite significant. Based on interviews with informants who perform backpacker umrah or what is known as independent umrah. It appears that on average, they only spend 15 million rupiahs and can save around 8-10 million rupiahs compared to taking a regular umrah package (Interview with Yusuf Al Ayubi, umrah travel agency officer based on Yogyakarta). 
When an umrah travel agency is willing to manage the land arrangement for umrah participants, which on average is pegged up to a maximum of USD 100 with a variety of available facilities, the bureau's profit margin is practically only on the following aspects: umrah visas, airport handling, all tips and taxes, tours experienced guides, city tours of Makkah, Medina, Jeddah (free snack), equipment (suitcases, ihrom, robe, and prayer books), and 5 liters of zam-zam. However, once again, this depends on the group's agreement departing because it is very tailor-made, adjusted to the needs and the agreement so that it dramatically affects the profit margin of the umrah travel agency.

\section{Conclusion}

Backpacker umrah, or what is known as independent umrah, is a phenomenon that continues to strengthen along with the increasing population of the Muslim urban middle class in Indonesia. The wave of umrah departure numbers continues to increase from year to year, at least until 2019. The motivation to participate in the umrah backpacker is due to the cost factor, especially for flight and hotel, but this is not a single factor. Another factor found in this study is that it has become the lifestyle of this Muslim urban middle class. With their welfare and better religious awareness, they express their religiosity with various Islamic lifestyles, one of which is choosing umrah. umrah is also done with backpackers or independently because most of them no longer want a tour around the city and various facilities that they think are not urgent and prefer to focus on worship, especially in the month of Ramadan.

Strict regulations have resulted in backpacker umrah participants not being able to travel for umrah on their own entirely. The cost that pilgrims can reduce the most is the plane ticket. For their needs while in Saudi Arabia, the rest need a land arrangement, played by a local travel agency in Saudi Arabia. Some backpacker umrah who do not have personal acquaintances can 
undoubtedly need an umrah travel agency in Indonesia to assist. For the umrah travel agency itself, facilitating an umrah land arranger for backpacker umrah pilgrims is also seen as a business opportunity. This study also found that the cost-effective umrah package prices directly by the umrah travel agency were not wholly economical. The total cost was not too far from the regular umrah price-it was just regular umrah with reduced facilities.

\section{References}

Adam, Issahaku. 2015. "backpackers' Risk Perceptions and Risk Reduction Strategies in Ghana." Tourism Management 49 (August): 99-108. https://doi.org/10.1016/j.tourman.2015.02.016.

Ali, Hasanuddin. 2017. "Pasar Kelas Menengah Muslim Yang Menggiurkan." Tirto.Id. 2017. https://tirto.id/pasar-kelas-menengah-muslim-yangmenggiurkan-cmw6.

Alves, Sandra, José Luís Abrantes, Maria José Antunes, Cláudia Seabra, and Ram Herstein. 2016. "WOM Antecedents in backpacker Travelers." Journal of Business Research 69 (5): 1851-56. https://doi.org/10.1016/j.jbusres.2015.10.068.

Anaira, Fika. 2019. "Persiapan Umroh Mandiri Dan Umroh backpacker - Food, Travel and Lifestyle Blog." November 15, 2019. https://www.diarysivika.com/2019/11/persiapan-umroh-mandiridan-umroh.html.

Arif, Firman Muhammad. 2019. "Penyelenggaraan Ibadah umrah Berbasis Maslahat." Al-Amwal: Journal of Islamic Economic Law 4 (1): 22-39. https://doi.org/10.24256/alw.v4i1.1180.

Dani, Akhmad Anwar. 2018. "Problematika Pengelolaan Penyelenggaraan umrah Di Kota Surakarta." Ilmu Dakwah: Academic Journal for Homiletic Studies 12 (1): 23-45. https://doi.org/10.15575/idajhs.v12i1.1903.

Dewi, Subkhani Kusuma. 2017. "Trend Wisata umrah: Antara Meneladani Sunnah Dan Turisme Spiritual." EMPIRISMA 26 (2): 191-206. https://doi.org/10.30762/empirisma.v26i2.691.

Gautret, Philippe, Terapong Tantawichien, Vinh Vu Hai, and Watcharapong Piyaphanee. 2011. "Determinants of Pre-Exposure Rabies Vaccination 
Not Only About Price but Also Lifestyle: Recent Phenomena of ...

among Foreign backpackers in Bangkok, Thailand." Vaccine 29 (23): 3931-34. https://doi.org/10.1016/j.vaccine.2011.03.096.

Haadiy, Fatahillah. 2015. Umroh backpacker: Cara Yang Benar Umroh Seribu Dollar. Tangerang Selatan: Ihsan Media.

Hefner, Robert W. 2017. "Christians, Conflict, and Citizenship in MuslimMajority Indonesia." The Review of Faith \& International Affairs 15 (1): 91-101. https://doi.org/10.1080/15570274.2017.1284403.

Hidayat, Nordin. 2019. umrah Anti-Mainstream. Edited by Luqman Hakim Rahman, Mujib \& Arifin. 1st ed. Jakarta: Rene Turos Indonesia.

Indonesia, Minister of Religious Affair Republic of. 2018. Regulation of the Minister of Religion of Republic of Indonesia No. 8. Indonesia.

Intansari, Anggita Isty, and Fitri Hidayatuz Zahroh. 2019. "Pembiayaan Ibadah umrah Pada Lembaga Keuangan Syariah." Indonesian Journal of Islamic Business and Economics 1 (1): 1-6. https://doi.org/10.20884/1.ijibe.2019.1.1.2205.

Jarvis, Jeff, and Victoria Peel. 2010. "Chapter 3. Flashpacking in Fiji: Reframing the 'Global Nomad' in a Developing Destination." In Beyond backpacker Tourism, edited by Kevin Diekmann and Hannam and Anya, 21-39. Multilingual Matters. https://doi.org/10.21832/9781845411329-006.

Jati, Wasisto Raharjo. 2015. "Islam Populer Sebagai Pencarian Identitas Muslim Kelas Menengah Indonesia." Teosofi: Jurnal Tasawuf Dan $\begin{array}{llll}\text { Pemikiran } & \text { Islam } & 5 & \text { (1): }\end{array}$ https://doi.org/10.15642/teosofi.2015.5.1.139-163.

Majstorovic, Vukica, Ugljesa Stankov, and Sanja Stojanov. 2013. “The Presence of Backpacking Tourism in Europe." Turizam 17 (4): 145-54. https://doi.org/10.5937/Turizam1304145M.

Maoz, Darya. 2007. "backpackers' Motivations the Role of Culture and Nationality." Annals of Tourism Research 34 (1): 122-40. https://doi.org/10.1016/j.annals.2006.07.008.

Markward, Anne. 2008. "backpacker: The Next Generation?" https://openrepository.aut.ac.nz/handle/10292/435.

Masruroh, Nikmatul. 2020. "The Competitiveness of Indonesian Halal Food Exports in Global Market Competition Industry." Economica: Jurnal 
Pitaya, Ghifari Yuristiadhi Masyhari Makhasi, and Mohd Hafiz Hanafiah

$\begin{array}{llll}\text { Ekonomi } & \text { Islam } & 11 & \text { (1): }\end{array}$ https://doi.org/10.21580/economica.2020.11.1.3709.

Moleong, Lexy J. 2014. Metode Penelitian Kualitatif. Bandung: PT Remaja Rosdakarya.

Mukhlis, Sihabudin. 2018. "Perlindungan Hukum Jemaah umrah Dalam Penyelenggaraan Perjalanan Ibadah umrah." Asy-Syari'ah 20 (1): 49-58. https://doi.org/10.15575/as.v20i1.3011.

Oktaviani, Nia, and Siti Sauda. 2019. "Pemodelan Dan Implementasi Aplikasi Mobile umrah Guide Menggunakan Unified Modeling Language." Jurnal $\begin{array}{lllll}\text { Sains Dan Informatika } 5 & \text { (2): 177-86. }\end{array}$ https://doi.org/10.34128/jsi.v5i2.184.

Oktaviani, Zahrotul. 2018. "Jamaah umrah Terus Meningkat, Apa Penyebabnya?" Republika. 2018. https://www.republika.co.id/berita/jurnal-haji/berita-jurnalhaji/18/12/15/pjr2vr313-jamaah-umrah-terus-meningkat-apapenyebabnya?

Oktoyadi, Oktoyadi, and Sri Wahyuni. 2019. "Kelayakan Pengembangan Bisnis E-Marketplace Perjalanan Ibadah umrah Pada PT. Sarana Transwisata Teknologi." Jurnal Riset Perbankan Manajemen Dan Akuntansi 3 (2): 13243. perbanas.ac.id/index.php/jrpma/article/view/44.

http://www.jrpma.sps-

0' Regan, Michael. 2010. "backpacker Mobilities: The Practice and Performance of Travellerscapes in a Global World."

Pearce, Philip L. 1990. The backpacker Phenomenon: Preliminary Answers to Basic Questions. Queensland: Department of Tourism, James Cook University of North Queensland.

Pearce, Philip L., and Faith Foster. 2007. "A 'University of Travel': backpacker Learning." Tourism Management 28 (5): 1285-98. https://doi.org/10.1016/j.tourman.2006.11.009.

Pitaya, Pitaya, Muhammad Baiquni, Marsono Marsono, and Nopirin Nopirin. 2019. "Paradigma Historis Backpacking Travel Sebagai Perjalanan Wisata." Jurnal Pariwisata Terapan 3 (1): 34. https://doi.org/10.22146/jpt.49274.

Prihantoro, F, and G Yuristiadhi. 2018. "Behavior of Tourists and the Future of Middle Class Tourism: A Phenomenological Study of Sunan Giri and 
Not Only About Price but Also Lifestyle: Recent Phenomena of ...

Sunan Drajat Tombs." KnE Social Sciences 3 (5): 211. https://doi.org/10.18502/kss.v3i5.2334.

Prihantoro, Fahmi, Ghifari Yuristiadhi Masyhari Makhasi, and Muhammad Rosyid Abdillah. 2019. "Reading Anomaly of Tourist Satisfaction in Pilgrimage Tourist Destination of Sunan Muria Tomb, Kudus, Central Java." E-Journal of Tourism 6 (1): 65. https://doi.org/10.24922/eot.v6i1.42917.

Prodjo, Wahyu Adityo. 2017. “Sejak Kapan umrah 'backpacker' Mulai Populer? Artikel Ini Telah Tayang Di Kompas.Com Dengan Judul "Sejak Kapan umrah 'backpacker' Mulai Populer?" Kompas. June 2017. https://travel.kompas.com/read/2017/06/02/210500727/sejak.kapa n.umrah.backpacker.mulai.populer.

Rohilah, Yeyet. 2018. “Efektivitas Kebijakan Kementerian Agama RI Terhadap Penyelenggara Perjalanan Ibadah umrah (PPIU) Dan Perlindungan Jemaah." Jakarta.

Rohmatillah, Layli, and Zainur Ridho. 2021. "Efektivitas Manajemen Layanan Prima Ibadah umrah PT Nur Haramain Mulia." Haramain 1 (1). http://jurnal.stebibama.ac.id/index.php/JMB/article/view/28.

Ronan, Romli. 2018. "Dana Talangan umrah Dalam Perspektif Hukum Islam." Jurnal Ilmiah Mizani: Wacana Hukum, Ekonomi Dan Keagamaan 5 (1): 29-46. https://doi.org/10.29300/mzn.v5i1.1435.

Setiawan, Wawan, and Ani Oktarini Sari. 2020. "Sistem Informasi Pelayanan Perjalanan Ibadah umrah." Jurnal Infortech 2 (1): 89-95. https://doi.org/10.31294/infortech.v2i1.8078.

Shamsuddin, Mustafa Mat Jubri. 2019. "Aplikasi Maslahah Ke Atas Pensyaratan Pelaksanaan Haji Atau umrah Melalui Agensi Pengelola." Sains Insani 4 (1): 15-21. https://doi.org/10.33102/jsi2019.4.1.03.

Subana, M., and Sudrajat. 2011. Dasar-Dasar Penelitian Ilmiah. Bandung: Pustaka Setia.

Syafira, Wirdahani, and Alim Murtani. 2020. "Pelayanan Dan Kenyamanan Biro Perjalanan umrah (Studi Kasus Pada PT. Gadika Expressindo Medan)." Al Qasd 2 (1): 40-48. https://doi.org/10.22303/alqasd.2.1.2020.40-48.

Wallstam, Martin. 2011. "backpacker Institutionalization: Towards an Experience-Based Typology."

Economica: Jurnal Ekonomi Islam - Volume 12, Nomor 1 (2021)

https://journal.walisongo.ac.id/index.php/economica 
Pitaya, Ghifari Yuristiadhi Masyhari Makhasi, and Mohd Hafiz Hanafiah

Walsh, Neil Michael. 2014. "The Social Performance of Backpacking: An Ontogenesis. How Are Backpacking Identities Organised, Constituted and Performed?" University of Otago.

Yusdani, Yusdani, Hujair AH Sanaky, Edi Safitri, Imam Machali, and Muhammad Iqbal Juliansyahzen. 2020. "Yogyakarta Urban Middle-Class Sufism: Economic, Political and Cultural Networks." Ulumuna 23 (2): 266-93. https://doi.org/10.20414/ujis.v23i2.342. 